\title{
Design \& Demonstration of Pilot Scale Continuous Stirred Tank Bioreactor for Biogas Production
}

\section{Sharma $\mathbf{R}^{*}$}

Department of Chemistry, Uttaranchal University, Dehradun, India

*Corresponding author: Rajan Sharma, Department of Chemistry, Uttaranchal University, Dehradun, India, Tel: $0135 \quad 277$ 2135; E-mail: sharmarajans21@gmail.com

\section{Research Article \\ Volume 1 Issue 1}

Received Date: August 24, 2016

Published Date: September 06, 2016

DOI: $10.23880 / \mathrm{cclsj}-16000104$

\section{Abstract}

Anaerobic digestion (AD) systems are extremely sensitive to changes in environmental variables. Correct design and control of the system's parameters are essential to maximize process efficiency, increase stability, and prevent system failure. Automation systems can both raise plant availability and help meet the transparency requirements of the process. A fully automated Continuous Stirred Tank Reactor (CSTR) of $40 \mathrm{~m}^{3}$ capacity was designed for jatropha waste and installed at University of Petroleum \& Energy Studies, Dehradun (India). This is first fully automated digestor at pilot scale which can be monitored by remote sensing all over the country. Parameters ( $\mathrm{pH}$, temp, feeding rate, energy consumption) were attained from a CSTR plant online by using Remote monitoring system. Pilot scale CSTR was operated using cow dung: jatropha de-oiled cake (CD: JDOC) in a optimized ratio of 1:3. The reactor was run continuously for 120 days. Average biogas produced per day was $25 \mathrm{~m}^{3}$ per day.

Keywords: Anaerobic digestion, automation, remote sensing, biogas

\section{Introduction}

Biogas technology provides an alternative source of energy to be utilized either as transportation fuel or as cooking fuel or for electricity generation mainly from organic wastes, viz cattle dung, kitchen waste, etc. Apart from this huge amount of lignocellulosic waste is also available for its effective conversion to biogas. The potential of jatropha de-oiled seed cakes for the generation of methane has long been recognized [1-3]. Biochemical methane potential (BMP) of various parts of jatropha plant has been investigated by Gunaseelan [4]. Studies on anaerobic digestion of J. curcas fruit shells (Hulls) indicate the production of about $2.5 \mathrm{~L}$ biogas with $70 \% \mathrm{CH}_{4}$ at $4 \mathrm{~g}$ VS (volatile solid) [5]. It has been reported that jatropha de-oiled cake (JDOC) produced biogas yield of $355 \mathrm{~L} \mathrm{~kg}^{-1}$ [6-7]. Although not very popular, but awareness about the usage of biogas is increasing dayby-day resulting in the number of biogas plants in the country, that too at community level (plants bigger than $15 \mathrm{~m}^{3}$ capacity). At such a large scale, it becomes difficult to monitor all the operating conditions of the plant manually. Thus integration of plant operation and its remote monitoring has become a necessity in the present scenario.

Automation systems have their unique advantages, like they help in raising plant availability and meeting the transparency requirements of the process. Operational efficiency and biogas yields are potentially raised through gathering various types of data, which must also be available for further processing. Information can include flow rates, pressures or fill levels as well as motor performance data or methane content. Some parameters 


\section{Cell \& Cellular Life Sciences Journal}

must be monitored cyclically. It is important, for instance, to ensure that the fermentation process runs smoothly. If the bacteria in the fermenter are not "fed" for six hours, methane production drops significantly. Gas and energy production must also be documented along with the quantities of all feed materials. By constantly checking ingredients, operators can monitor and control the fermentation process to maintain the quality of the generated biogas. To achieve this, all subsystems must communicate simply and securely with each other. For this purpose, industrial Ethernet has become the standard for meeting the industrial sector's need for robust communication systems that can reliably transfer data over long distances. If talked in long run, integrated robust complete systems based on durable, flexible industrial solutions are the best investment for plant operators.

Keeping in view the significance and necessity of automation in this technology, a fully automated Continuous Stirred Tank Reactor (CSTR) of $40 \mathrm{~m}^{3}$ capacity was designed for jatropha waste and installed at the campus of University of Petroleum \& Energy Studies, Dehradun (India) in 2013. This is the first fully automated digestor at pilot scale which can be monitored by remote sensing from all over the country.

\section{Experimental Details}

The CSTR was designed taking the concentration of slurry and biochemical methane potential of JDOC in consideration. The components of CSTR Biogas digester include $5 \mathrm{~mm}$ thick MS plate with angle support and fibres glass reinforced plastics (FRP) lining $1 \mathrm{~mm}$ thick, 2 HP Flange mounted vertical stirrer system, 3 HP shredder, $1 / 2$ HP screw slurry pump, and Remote monitoring system which allowed the constant monitoring of the operating parameters of the plant to understand its efficiency.

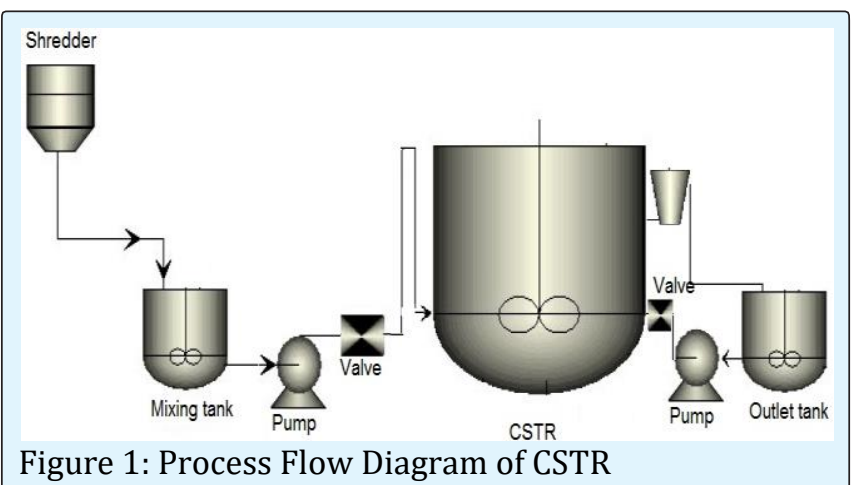

Sharma R. Design \& Demonstration of Pilot Scale Continuous Stirred Tank Bioreactor for Biogas Production. Cell Cellular Life Sci J 2016, 1(1): 000104.

Figure 1: Process Flow Diagram of CSTR
Actual plant constructed on this basis is shown in (Figure 2).

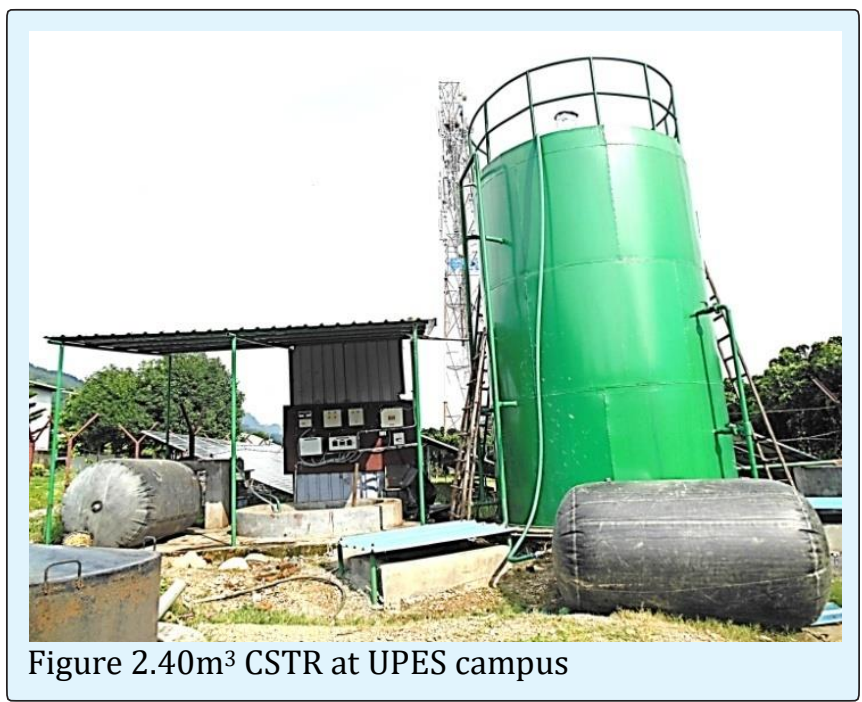

Ratio of JDOC and cow dung (to be fed in pilot scale digester) was optimized at lab scale (Figure 3).

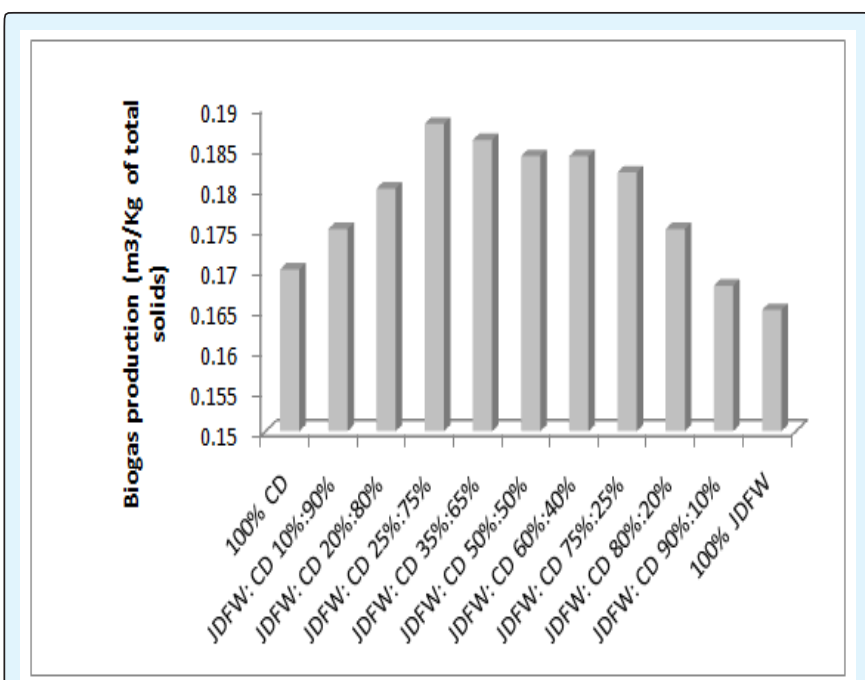

Figure 3: Ratio optimization of feed stock at lab scale

Maximum production was observed in the mixture of JDOC and cow dung in a ratio of 25:75, but the objective was to shift the plant on JDOC up to the best possible extent. Hence, 75:25 ratio of JDOC and cow dung was chosen as an optimum ratio and fed in pilot scale plant, with a continuous monitoring of $\mathrm{pH}$, temperature and gas production for 120 days. 


\section{Cell \& Cellular Life Sciences Journal}

\section{Results \& Discussion}

Monitored data was stored in the automated system through remote sensing which was used to analyse the performance of the plant (Figure 4).

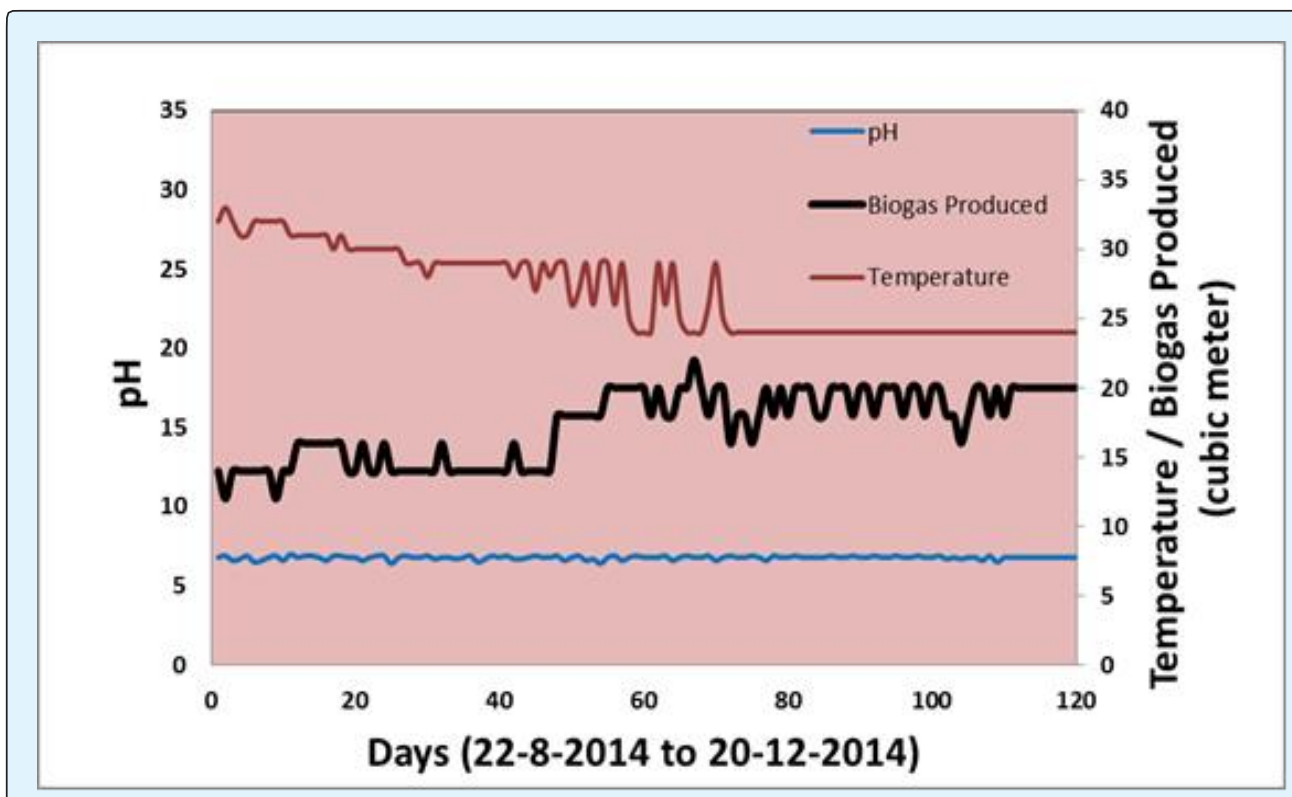

Figure 4: Operational results of pilot scale CSTR for 04 months

Results indicate that initially production of biogas was lower which eventually increased with time. The possible reason for this is that initially decomposition of biomass was slow and it took around 15 days to start for gas production. Once the micro-organisms were grown properly, the process was zoomed up leading to increased production of biogas. Later stages show continuously higher production of biogas which is also due to decreased HRT. In CSTR, out coming slurry (already containing grown micro-organisms) was recycled to the digester, which helped in reducing the HRT from 15 to 5 days with the production of around $25 \mathrm{~m}^{3}$ biogas/day.

\section{Conclusion and Recommendation}

Automated biogas plants are beneficial for community based digesters in the villages. Successful implementation of the process at pilot scale can recommend the technology to be adopted at industrial level as two major advantages are associated with the use of CSTR, i.e. it helps in the reduction of hydraulic retention time; and the operation can be monitored and guided for better performance optimizing the production of biogas.

\section{Acknowledgement}

Authors acknowledge the financial support provided by Ministry of New and Renewable Energy (MNRE), New Delhi, India (MNRE Sanction Order No: 19-1/2011$\mathrm{BE} / \mathrm{R} \& \mathrm{D})$.

\section{References}

1. Gollakota KG, Jayalakshmi B (1983) Biogas (natural gas?) production by anaerobic digestion of oil cake by a mixed culture isolated from cow dung. Biochem Biophys Res Commun 110(1): 32-35.

2. Lingaiah V, Rajasekaran P (1986) Biodigestion of cow dung and organic wastes mixed with oil cake in relation to energy. Agricultural wastes 17(3): 161173.

3. Radhakrishna P, Gollakota KG (1989) A pilot plant design and performance for biomethanation of nonedible oil cakes. Energy 14(11): 771-772. 


\section{Cell \& Cellular Life Sciences Journal}

4. Gunaseelan VN (2009) Biomass estimates, characteristics, biochemical methane potential, kinetics and energy flow from Jatropha curcus on dry lands. Biomass and Bioenergy 33(4): 589-596.

5. Lopez O, Foidl G, Foidl N (1997) Production of biogas from Jatropha curcus fruit shells. In: Symposium on Jatropha 97. Austria: Austrian Ministry of Foreign Affairs.
6. Staubmann R, Foidl G, Foidl N, Gubitz GM, Lafferty RM, et al. (1997) Production of biogas from Jatropha curcus seeds press cake. In: Symposium on Jatropha 97. Austria: Austrian Ministry of Foreign Affairs.

7. Chandra R, Vijay VK, Subbarao PMV (2006) A study on biogas generation from non-edible oil seed cakes: potential and prospects in India. The Second joint International conference on "Sustainable energy and environment (SEE 2006)" Bangkok, Thailand. 